\title{
Biotechnological bases of the development of cloned pig embryos
}

\author{
A.V. Lopukhov@, G.N. Singina, N.A. Zinovieva \\ Federal Science Center for Animal Husbandry named after Academy Member L.K. Ernst, Moscow, Russia \\ 凶e-mail:vubi_myaso@mail.ru
}

\begin{abstract}
The term 'clone' in animal biotechnology refers to an organism derived from non-sexual reproduction, which is both a direct offspring and a genetic copy of the parent organism. To date, the pig appears to be the most interesting object in cloning research. Somatic cell nuclear transfer in pigs has a wide range of potential applications in various fields of human scientific and economic activities. However, the efficiency of producing cloned embryos in swine is still lower than that of other livestock species, in particular horses and cattle. Somatic cell nuclear transfer is a technically complex multi-stage technology, at each stage of which the pig oocytes, which are more susceptible to changes of surrounding conditions, are affected by various factors (mechanical, physical, chemical). At the stage of oocyte maturation, changes in the cell ultrastructures of the ooplasm occur, which play an important role in the subsequent nuclear reprogramming of the transferred donor cell. Before transfer to the oocyte donor somatic cells are synchronized in the G0/G1 stage of the cell cycle to ensure the normal ploidy of the cloned embryo. When removing the nucleus of pig oocytes maturated in vitro, it is necessary to pay attention to the problem of preserving the viability of cells, which were devoid of their own nuclear material. To perform the reconstruction, a somatic cell is placed, using micro-tools, in the perivitelline space, where the first polar body was previously located, or in the cytoplasm of an enucleated oocyte. The method of manual cloning involves the removal of the oocyte nucleus with subsequent fusion with the donor cell without the use of micromanipulation techniques. The increased sensitivity of oocytes to the environmental conditions causes special requirements for the choice of the system for in vitro culture of cloned pig embryos. In this work, we have reviewed the modern methods used for the production of cloned embryos and identified the technological issues that prevent improving the efficiency of somatic cloning of pigs.
\end{abstract}

Key words: domestic pig; Sus scrofa domestica; oocytes; in vitro; somatic cell nuclear transfer; fusion; activation; cloned embryo.

For citation: Lopukhov A.V., Singina G.N., Zinovieva N.A. Biotechnological bases of the development of cloned pig embryos. Vavilovskii Zhurnal Genetiki i Selektsii = Vavilov Journal of Genetics and Breeding. 2019;23(5): 527-533. DOI 10.18699/VJ19.521

\section{Биотехнологические основы получения клонированных эмбрионов свиней}

\author{
А.В. Аопухов @, Г.Н. Сингина, Н.А. Зиновьева \\ Федеральный научный центр животноводства - ВИЖ им. академика Л.К. Эрнста, Москва, Россия \\ هe-mail:vubi_myaso@mail.ru
}

Термин «клон» в биотехнологии животных обозначает организм, полученный в результате неполового размножения, который одновременно является прямым потомком и генетической копией родительского организма. На сегодняшний день домашняя свинья (Sus scrofa domestica) представляется наиболее интересным объектом в исследованиях по клонированию. Клонирование свиней имеет широкий спектр потенциальных возможностей использования в различных областях научной и хозяйственной деятельности человека. Тем не менее эффективность получения клонированных эмбрионов свиней все еще остается ниже, чем других видов сельскохозяйственных животных, в частности лошадей и крупного рогатого скота. Соматическое клонирование - сложная многоступенчатая технология, на каждом этапе которой более восприимчивые к изменениям окружающих условий ооциты свиней испытывают неблагоприятные воздействия различных по своей природе факторов (механические, физические, химические). На этапе созревания ооцитов происходят изменения клеточных ультраструктур ооплазмы, которые играют важную роль в последующем репрограммировании ядра пересаженной донорской клетки. Донорские соматические клетки перед переносом в ооцит синхронизируют в стадии G0/G1 клеточного цикла с целью обеспечения нормальной плоидности клонированного эмбриона. При удалении ядра у созревших in vitro ооцитов свиней следует обращать внимание на проблему сохранения жизнеспособности клеток после извлечения собственного ядерного материала. В ходе реконструирования соматическую клетку с помощью микроинструментов помещают в перивителлиновое пространство, где ранее находилось первое 


\begin{abstract}
полярное тельце, или в цитоплазму энуклеированного ооцита. Метод ручного клонирования (handmade cloning) предполагает удаление ядра ооцита с последующим слиянием с донорской клеткой без помощи микроманипуляционной техники. Повышенная чувствительность ооцитов к факторам окружающей среды обусловливает особые требования к выбору системы in vitro культивирования клонированных эмбрионов свиней. В рамках настоящего обзора проведен мониторинг современных методов, используемых при получении клонированных эмбрионов, выявлены технологические особенности, препятствующие повышению эффективности метода соматического клонирования свиней.

Ключевые слова: домашняя свинья; Sus scrofa domestica; ооциты; in vitro; соматическое клонирование;
\end{abstract} слияние; активация; клонированный эмбрион.

\section{Introduction}

The ability of the somatic cell nucleus, which is transferred to the enucleated oocyte, to be reprogramed is one of the most important phenomena of biological science, the discovery of which made it possible to obtain reconstructed embryos and cloned animals. In practice, this was implemented in June 1996 by a group of Scottish researchers led by Ian Wilmut, who reported the birth of the first cloned mammal (Dolly the sheep) with hereditary material identical to another adult animal, which was produced using differentiated cells (breast epithelium) (Wilmut et al., 1997). The serious interest of the scientific community, caused by the revolutionary breakthrough in this field of reproductive technologies, has led to the cloning of more than 20 mammalian species (Singina et al., 2014).

The production of cloned piglets was conducted for the first time in 2000 simultaneously by two research groups from the United States and Japan (Onishi et al., 2000; Polejaeva et al., 2000). One of the main application fields of cloning technology is the use of genetically modified pigs as models for the study of human diseases and organ donors for xenotransplantation (Betthauser et al., 2000). Currently, such animals are used in preclinical testing of preventive or therapeutic medicines (Liu et al., 2008), testing the toxicity of drugs, studies of functional genomics (Wimmers et al., 2010). Production of genetically modified pigs is a potential tool for reducing physiological and immunological barriers to obtaining and transplantation of donor organs. Another equally important area of practical application of cloning is the production of animals with desired parameters of productivity by copying boars and sows with high breeding values.

At somatic cloning, instead of its own chromosomal material, the oocyte (cytoplast) acquires the nucleus of a somatic cell (karyoplast) from the animal, a genetic copy of which is to be obtained. The main stages of the cloning technology included the preparation (in vitro maturation) of the recipient oocyte and donor cells, removing nuclear material from the mature oocyte, reconstruction of the cytoplast obtained (fusion with karyoplasts), activation of the reconstructed oocyte and culture of the cloned embryo (Niemann et al., 2011; Simões, Santos, Jr., 2017).

\section{Oocyte maturation}

The ability of the oocyte to initiate successful development into the cloned, parthenogenetic embryo and the embryo after in vitro fertilization is largely determined by its maturation. Cytoplasmic maturation includes modifications of the cytoplasm, in particular, redistribution of organelles, changes in cytoskeletal dynamics, micro- and macromolecular alterations
(Ferreira et al., 2009). Nuclear maturation involves modifications of chromatin during the period from the destruction of the germinal vesicle to the metaphase of the second meiotic division (MII) (Marteil et al., 2009).

Unlike in vitro culture of other animal species, that of pig oocytes relies on a two-phase maturation protocol is used, which makes it possible to increase their competence to fertilization or to artificial activation. At the first stage, the proteins that are necessary for the early embryonic development are produced in the oocyte under the action of hormones. The second period of maturation takes place without external signals and includes the division of the nucleus and the structuring of cell organelles. The matured oocytes at the stage of metaphase II with the visualized first polar body are usually used as sources of cytoplasts for cloning (Hardarson et al., 2000). In pigs, the optimal duration of in vitro maturation of oocytes varies according to different studies in the range from 24 to 44 hours (Zhang et al., 2006; Sugimura et al., 2010).

\section{Preparation of donor somatic cells}

The efficiency of reprogramming after transfer of somatic cell nuclei depends on a number of factors, including the type, the number of passages and the stage of the cell cycle of the donor cell (Enright et al., 2003; Yang et al., 2007). Particular importance for the success of cloning has the level of differentiation of the donor cell (Jaenisch, 2012). To date, cloned swine embryos have been produced using different types of somatic cells, such as fetal fibroblasts, skin fibroblasts, neural stem cells, cumulus cells, granulosa cells and breast epithelial cells (Verma et al., 2000; Cervera et al., 2009; Zheng et al., 2009).

A necessary condition for nucleus reprogramming and for the successful development of the cloned embryo is the synchronization of the cell cycle of the cytoplast and karyoplast. With this aim, the donor cells of all types are normally subjected to artificial arrest in phase G0/G1 prior to micromanipulation procedures (Boquest et al., 1999). The transfer of somatic cell nuclei, of which DNA has not been replicated yet, to the oocyte at metaphase II reduces the risk of chromosomal abnormalities and ploidy disorders of cloned embryos (Campbell et al., 1996). Coordination between the cell cycles of oocytes and somatic cells of pigs is ensured by limitation of serum content or by contact inhibition. Despite the fact that the first cloned piglets were obtained after transfer of donor cell nuclei after the limitation of serum content (Polejaeva et al., 2000), this method is characterized by negative effects. One, for example, is the initiation of apoptotic phenomena along with increased DNA fragmentation at the culture of swine fibroblasts in a medium with a low serum content (Kues et al., 
2002). The most commonly used method for synchronizing the cell cycle in a pig cloning procedure is contact inhibition of somatic cells in confluence (Park et al., 2010). In addition, chemical antimitotic agents (mimosine, rapamycin, roscovitine etc.) have become more broadly applied in the recent years (Vacková et al., 2003; Park et al., 2010; Hyun et al., 2016).

\section{Removal of the nuclear material of oocytes}

Complete removal of nuclear material from the mature oocyte eliminates the possibility of aneuploidy, reduces the risk of spontaneous parthenogenetic activation and abnormal development of the cloned embryo. However, due to the presence of fat inclusions in the cytoplasm, the nuclei of swine oocytes are not visualized under an inverted microscope without prior staining of DNA with fluorochrome dyes in combination with ultraviolet visualization (Tatham et al., 1995). The disadvantage of the classical technique is the damage of mitochondrial DNA and ooplasmic organelles by ultraviolet light. Therefore, an alternative method of blind enucleation is used, which is based on the assumption that metaphase chromosomes in mature oocytes are attached to the mitotic spindle, and their position is determined by an indirect sign, the localization of the first polar body (FPB). Thus, after removal of the FPB and part of the cytoplasm, the mature oocyte also loses the metaphase plate (McGrath, Solter, 1983). The disadvantage of this approach is the migration of the FPB relative to the metaphase plate (Hardarson et al., 2000; Miao et al., 2004) due to aging of mature oocytes (Miao et al., 2009).

Another method of enucleation is based on the cutting of the zona pellucida close to the FBP with subsequent compression of the oocyte by a glass needle to remove a small volume of the ooplasm. The removed ooplast remains intact and is therefore convenient for DNA staining to confirm removal of the mitotic spindle without exposing the oocyte to the harmful effects of ultraviolet light. The disadvantage of the procedure is its complexity and difficulty to control the volume of the removed cytoplasm. The compression method, which is associated with removal of the metaphase plate by releasing part of the cytoplasm of the mature swine oocyte in vitro, is a time-consuming procedure, which is characterized by a higher rate of degeneration compared to the classical method (Lee et al., 2008).

In 2002, a group of researchers reported on the production of cloned piglets after chemical enucleation (Yin et al., 2002). Chemical enucleation is based on the use of topoisomerase II inhibitors blocking the onset of telophase II, resulting in the expelling of mitotic spindle to the cell boundary (Fulka, Mur, 1993; Savard et al., 2004). A short exposition of pig oocytes at metaphase II in $0.4 \mathrm{mg} / \mathrm{ml}$ demecolcine - a chemical agent causing the depolymerization of microtubules - in the presence of $0.05 \mathrm{M}$ solution of sucrose causes membrane protrusion containing a condensed chromosome mass, which can be easily removed through aspiration (Kawakami et al., 2003).

\section{The reconstruction of the oocytes with the aim of producing cloned embryos}

The traditional method of reconstruction involves the transplantation of a donor cell into the perivitelline space of the recipient oocyte. After fixation of the oocyte with a holding pipette, the somatic cell is transferred to the oocyte through a hole or incision formed during enucleation using a transfer pipette (Popova et al., 2009). At intracytoplasmic injection, the karyoplast is introduced directly into the cytoplasm of the enucleated oocyte, bypassing the perivitelline space (Onishi et al., 2000; Lee et al., 2003; Kong et al., 2008). The factor limiting the use of this method of producing cloned embryos is the incomprehensible mechanism of destruction of the donor cell membrane in the cytoplasm of the recipient oocyte. In the case of maintaining the integrity of the membrane of the transferred cell, and thus, not passing the reprogramming of its nucleus during intracytoplasmic injection, embryos do not develop further (Lee et al., 2003).

Cloned embryos can be produced without the use of micromanipulation techniques (Vajta et al., 2005). In the framework of the method of manual cloning (Hand Made Cloning, HMC), oocytes at metaphase II are released from the zona pellucida with the help of the enzyme pronase, cut by a microscalpel into two equal parts, which are stained with the vital fluorescent dye Hoechst 33342 in order to accurately detect the location of the metaphase plate. Two halves of oocytes that do not contain chromatin are selected for fusion with the somatic cell (Vajta et al., 2001). The successful use of this method to produce cloned pigs has been reported (Kragh et al., 2004). The limiting factor in ensuring the reproducibility of the HMC technology is the need to set up adequate conditions for culture of zona pellucida free embryos. The use of two mature oocytes to produce one reconstructed embryo by the HMC method results in the loss of $50 \%$ of the initial material. The presence in the HMC embryos of three genotypes of mitochondrial DNA potentially increases the level of mitochondrial heteroplasmy (Oback et al., 2003).

The development of a cloned embryo is impossible without the fusion of the recipient oocyte with the transferred donor cell. In the practice of somatic cloning, there is a technique called 'electrofusion', which is fusion of the cytoplast and the karyoplast with the use of the phenomenon of electric breakdown of the membranes of the contacting pair in a pulsed electric field. The procedure of electrofusion involves the use of two types of electrical signals, inhomogeneous AC pulses and rectangular DC pulses. The electrical oscillations that occur during electrofusion cause excessive heating of the medium with high conductivity. For this reason, buffer solutions with low electrical conductivity, which can cause the formation of dielectric potentials within the cells to facilitate intercellular contact, are chosen for electrofusion. Mainly, the Zimmerman medium in various modifications is used for cell fusion (Robl et al., 1987; Nickoloff, 1995). The physical factors affecting the effectiveness of the fusion of the cytoplast and karyoplast include voltage, duration and repeatability of the electric field pulse. As a rule, the effect of dielectrophoretic forces on the cells is caused by the guidance of a high-frequency $(1-3 \mathrm{MHz})$ sinusoidal AC field of low amplitude $(\sim 100-300 \mathrm{~V} / \mathrm{cm})$. Cells that come into contact with plasma membranes are fused by one or two rectangular pulses of high voltage DC $(1-10 \mathrm{kV} / \mathrm{cm})$ with a duration of 10-50 $\mu \mathrm{s}$ (Cao et al., 2008). The literature is rich in methods of cell electrofusion, which is due to both the technical characteristics of the devices used for these purposes, and the particularities of different types of cells. 


\section{Activation of reconstructed oocytes}

In the process of cloning, the enucleated oocytes after fusion with the diploid donor cell are activated for further development (Campbell, 1999). For cloning of pig embryos, the activation signals used are DC pulses (Im et al., 2004; Hölker et al., 2005), the chemical agents ionomycin, ionophore $\mathrm{Ca}^{2+} \mathrm{A} 23187$ (Yin et al., 2002; Hyun et al., 2003; Garcia-Mengual et al., 2008), and thimerosal in combination with dithiothreitol (Im et al., 2006; Whitworth et al., 2009). Among the existing methods, electrostimulation is the most commonly used for the production of cloned embryos. It is reported that the magnitude of the emission of $\mathrm{Ca}^{2+}$ ions is proportional to the number and magnitude of pores formed during electrical stimulation, and depends on the number and duration of electrical pulses and electric field strength (Fissore, Robl, 1992). One DC pulse leads to a single mobilization of intracellular calcium reserves. In contrast, the strategy of multiple electrical pulses (2-3) stimulates the generation of a long series of $\mathrm{Ca}^{2+}$ oscillator peaks, increasing many times the concentration of these cations in the ooplasm (Fissore et al., 1999).

In studies on somatic cloning of pigs (Verma et al., 2000; Zhu et al., 2002), the multiplication of electrical impulses positively correlated with the high level of development of reconstructed oocytes to the stage of morula and blastocysts. The specific feature of obtaining cloned pig zygotes is the simultaneous electroactivation and electrofusion of the enucleated oocyte and somatic donor cells (Hyun et al., 2003; Lee et al., 2003; Skrzyszowska et al., 2008). Transgenic cloned pig embryos produced from the oocytes reconstructed using fetal fibroblasts, which were activated by electric pulses and by subsequent incubation in a solution of ionomycin, were inferior in terms of development to the blastocyst stage to the oocytes fused with the somatic cell and activated simultaneously (Hyun et al., 2003). Simultaneous fusion and activation of pig oocytes led to the improvement of embryonal development of oocytes reconstructed using fetal fibroblasts compared to the use of shared electrical and chemical activation (Samiec, Skrzyszowska, 2010). At the same time, it should be noted that no clear and reproducible unified protocols of electrical activation - like those developed for other mammalian species - have yet been developed for pigs, and the parameters of the electric field (the number of electrical impulses, the duration of electrical stimulation and the interval between pulses) significantly vary (Koo et al., 2005; Cervera et al., 2010; Peng et al., 2013).

One of the approaches for increasing the effectiveness of artificial activation is the by using stimuli that increase the concentration of $\mathrm{Ca}^{2+}$ ions in the cytoplasm, in combination with factors that inhibit the activity of the maturation promoting factor (Presicce, Yang, 1994; Cheng et al., 2007). Electrical stimulation in conjunction with postactivation culture in the presence of 6-dimethylaminopurine (6-DMAP) or cycloheximide resulted in an increase in the yield of blastocysts compared to conventional electroactivation (Kim et al., 2005; Im et al., 2006). Culture in the presence of 6-DMAP after electrical stimulation leads to an increase in the oscillations of intracellular $\mathrm{Ca}^{2+}$ ions, which is observed throughout the entire period of postactivation of activated pig oocytes (Im et al., 2006, 2007). The combination of the chemical agents
6-DMAP + cytochalasin B improved the parthenogenetic development of embryos to the blastocyst stage, but these blastocysts were characterized by a reduced number of cells. Postactivation of pig oocytes in 6-DMAP increased the yield of blastocysts on day 7 of culture in comparison with the incubation in the presence of cycloheximide or cytochalasin B (Grupen et al., 2002).

\section{Culture of cloned embryos}

Activated reconstructed oocytes, which have started their embryonic development, are cultured in vitro in special media until transplantation to the recipient animal. As is known, when comparing in vivo and in vitro produced embryos, the latter have a reduced potential to embryonic development (Uhm et al., 2009; Gil et al., 2017). On the other hand, it has been shown that cloned embryos are more sensitive to culture conditions compared to parthenogenetic embryos (Heindryckx et al., 2001). These observations, along with the increased susceptibility of embryos to environmental factors when they are maintained outside the sow's body, including temperature fluctuations, set special requirements to the systems of in vitro culture of reconstructed pig oocytes. Culture media should provide overcoming a developmental arrest of 4-cell pig embryos, activation of the own genome and in vitro development to advanced stages of embryogenesis (morula and blastocyst).

Different media such as NCSU-23 and NCSU-37, BECM-3, PZM-3, PZM-4 and PZM-5 are used for culture of pig embryos (Dobrinsky et al., 1996; Yoshioka et al., 2002; Im et al., 2004). NCSU-23 is a traditional and initially widely used medium for the development of in vitro fertilized and cloned swine embryos. On the other hand, PZM-3, of which the composition is similar to the environment of the pig oviduct, allows increasing the ratio of embryos developed to the blastocyst stage at the 7th day of culture, and the number of cells of inner cell mass compared to NCSU-23 media (Im et al., 2004). Cloned embryos are known to be more susceptible to apoptotic degeneration than embryos developed after in vitro fertilization of intact oocytes (Ju et al., 2010). It has been shown that culture in PZM-5 developed by Japanese researchers in 2004 (Suzuki et al., 2004) reduces the apoptotic index in the pig embryos, produced by nuclei transfer of somatic cells (Yamanaka et al., 2009).

However, it should be noted that, despite the local successes in the development and application of new culture media, currently the conditions for embryo culture of this animal species are still not optimal. That is why, according to scientists from Canada (Cordova et al., 2017), in most of the experiments on nuclei transfer of somatic cells, the reconstructed embryos are transplanted to the host animals prior to or at early stages of cleavage. For example, a more efficient transplantation of embryos to the recipient sow was shown at hours 4-6 following activation of reconstructed oocytes than at hours 20-24 (1-2 cell embryos), the increase in efficiency being seen as an increase in pregnancy rate and the overall effectiveness of cloning (Shi et al., 2015). On the other hand, in vitro incubation to the morula and blastocyst stage allows controlling each division-cleavage with the possibility to select high-quality embryos with the greatest potential for further development (Jin et al., 2018). As confirmation of this 
suggestion, the extension of the duration of in vitro culture of cloned embryos from 20 to 40 hours increased the number of pregnant recipients by $13 \%$, and from 22 to 120 hours by $61.8 \%$ (Ju et al., 2010; Rim et al., 2013).

\section{Conclusion}

Analysis of literature data has shown that the cloning technology allows the researcher to create cloned pig embryos and to obtain viable offspring after transfer to the recipient animal. While some stages of cloning have become routine in many aspects (fusion, enucleation, reconstruction), others are still uncertain and require additional research (oocyte maturation, donor cells and embryo culture). It is also obvious that it will be necessary to pay special attention to studying the mechanisms of somatic cell reprogramming and regulation of oocyte quality - for using quality oocytes as sources of cytoplasts.

\section{References}

Betthauser J., Forsberg E., Augenstein M., Childs L., Eilertsen K., Enos J., Forsythe T., Golueke P., Jurgella G., Koppang R., Lesmeister T., Mallon K., Mell G., Misica P., Pace M., Pfister-Genskow M., Strelchenko N., Voelker G., Watt S., Thompson S., Bishop M. Production of cloned pigs from in vitro systems. Nat. Biotechnol. 2000; 18:1055-1059. DOI 10.1038/80242.

Boquest A.C., Day B.N., Prather R.S. Flow cytometric cell cycle analysis of cultured porcine fetal fibroblast cells. Biol. Reprod. 1999;60: 1013-1019. DOI 10.1095/biolreprod60.4.1013.

Campbell K.H. Nuclear transfer in farm animal species. Semin. Cell Dev. Biol. 1999;10(3):245-252. DOI 10.1006/scdb.1999.0310.

Campbell K.H., Loi P., Otaegui P.J., Wilmut I. Cell cycle co-ordination in embryo cloning by nuclear transfer. Rev. Reprod. 1996;1(1):4046. DOI 10.1530/ror.0.0010040.

Cao Y., Yang J., Yin Z.Q., Luo H.Y., Yang M., Hu N., Yang J., Huo D.Q., Hou C.J., Jiang Z.Z., Zhang R.Q., Xu R., Zheng X.L. Study of high-throughput cell electrofusion in a microelectrodearray chip. Microfluid. Nanofluidics. 2008;5:669-675. DOI 10.1007/ s10404-008-0289-1.

Cervera R.P., Marti-Gutierrez N., Escorihuela E., Moreno R., Stojkovic $M$. Trichostatin A affects histone acetylation and gene expression in porcine somatic cell nucleus transfer embryos. Theriogenology. 2009;72:10971110. DOI 10.1016/j.theriogenology.2009.06.030.

Cervera R.P., Silvestre M.A., Marti N., García-Mengual E., Moreno R., Stojkovic M. Effects of different oocyte activation procedures on development and gene expression of porcine pre-implantation embryos. Reprod. Domest. Anim. 2010;45:12-20. DOI 10.1111/j.14390531.2009.01509.x.

Cheng W.M., Sun X.L., An L., Zhu S.E., Li X.H., Li Y., Tian J.H. Effect of different parthenogenetic activation methods on the developmental competence of in vitro matured porcine oocytes. Anim. Biotechnol. 2007;18:131-141. DOI 10.1080/10495390601096148.

Cordova A., King W.A., Mastromonaco G.F. Choosing a culture medium for SCNT and iSCNT reconstructed embryos: from domestic to wildlife species. J. Anim. Sci. Technol. 2017;59:24. DOI 10.1186/ s40781-017-0149-1.

Dobrinsky J.R., Johnson L.A., Rath D. Development of a culture medium (BECM-3) for porcine embryos: effects of bovine serum albumin and fetal bovine serum on embryo development. Biol. Reprod. 1996;55(5):1069-1074.

Enright B.P., Kubota C., Yang X., Tian X.C. Epigenetic characteristics and development of embryos cloned from donor cells treated by Trichostatin A or 5-aza-2'-deoxycytidine. Biol. Reprod. 2003;69: 896-901. DOI 10.1095/biolreprod.103.017954.

Ferreira E.M., Vireque A.A., Adona P.R., Meirelles F.V., Ferriani R.A., Navarro P.A. Cytoplasmic maturation of bovine oocytes: structural and biochemical modifications and acquisition of developmen- tal competence. Theriogenology. 2009;71:836-848. DOI 10.1016/ j.theriogenology.2008.10.023.

Fissore R.A., Long C.R., Duncan R.P., Robl J.M. Initiation and organization of events during the first cell cycle in mammals: applications in cloning. Cloning. 1999;1(2):89-100. DOI 10.1089/ 15204559950019979.

Fissore R.A., Robl J.M. Intracellular $\mathrm{Ca}^{2+}$ response of rabbit oocytes to electrical stimulation. Mol. Reprod. Dev. 1992;32:9-16. DOI $10.1002 / \mathrm{mrd} .1080320103$

Fulka J., Moor R.M. Noninvasive chemical enucleation of mouse oocytes. Mol. Reprod. Dev. 1993;34:427-430. DOI 10.1002/mrd. 1080340412.

Garcia-Mengual E., Alfonso J., Salvador I., Duque C.C., Silvestre M.A. Oocyte activation procedures and influence of serum on porcine oocyte maturation and subsequent parthenogenetic and nuclear transfer embryo development. Zygote. 2008;16:279-284. DOI 10.1017/S0967199408004796.

Gil M.A., Martinez C.A., Nohalez A., Parrilla I., Roca J., Wu J., Ross P.J., Cuello C., Izpisua J.C., Martinez E.A. Developmental competence of porcine genome-edited zygotes. Mol. Reprod. Dev. 2017;84(9):814-821. DOI 10.1002/mrd.22829.

Grupen C., Mau J.C., McIlfatrick S.M., Maddocks S., Nottle M.B. Effect of 6-dimethylaminopurine on electrically activated in vitro matured porcine oocytes. Mol. Reprod. Dev. 2002;62:387-96. DOI 10.1002/mrd.10126.

Hardarson T., Lundin K., Hamberger L. The position of the metaphase II spindle cannot be predicted by the location of the first polar body in the human oocyte. Hum. Reprod. 2000;15(6):1372-1376. DOI 10.1093/humrep/15.6.1372.

Heindryckx B., Rybouchkin A., Van Der Elst J., Dhont M. Effect of culture media on in vitro development of cloned mouse embryos. Cloning. 2001;3(2):41-50. DOI 10.1089/15204550152475545.

Hölker M., Petersen B., Hassel P., Kues W.A., Lemme E., LucasHahn A., Niemann H. Duration of in vitro maturation of recipient oocytes affects blastocyst development of cloned porcine embryos. Cloning Stem Cells. 2005;7:35-44. DOI 10.1089/clo.2005.7.35.

Hyun H., Lee S.E., Son Y.J., Shin M.Y., Park Y.G., Kim E.Y., Park S.P. Cell synchronization by rapamycin improves the developmental competence of porcine SCNT embryos. Cell. Reprogram. 2016; 18(3):195-205. DOI 10.1089/cell.2015.0090.

Hyun S., Lee G., Kim D., Kim H., Lee S., Nam D., Jeong Y., Kim S., Yeom S., Kang S., Han J., Lee B., Hwang W. Production of nuclear transfer-derived piglets using porcine fetal fibroblasts transfected with the enhanced green fluorescent protein. Biol. Reprod. 2003;69: 1060-1068. DOI 10.1095/biolreprod.102.014886.

Im G.S., Lai L., Liu Z., Hao Y., Wax D., Bonk A., Prather R.S. In vitro development of preimplantation porcine nuclear transfer embryos cultured in different media and gas atmospheres. Theriogenology. 2004;61(6):1125-1135. DOI 10.1016/j.theriogenology.2003. 06.006 .

Im G.S., Samuel M., Lai L., Hao Y., Prather R.S. Development and calcium level changes in pre-implantation porcine nuclear transfer embryos activated with 6-DMAP after fusion. Mol. Reprod. Dev. 2007;74:1158-1164. DOI 10.1002/mrd.20492.

Im G.S., Seo J.S., Hwang I.S., Kim D.H., Kim S.W., Yang B.C., Yang B.S., Lai L., Prather R.S. Development and apoptosis of preimplantation porcine nuclear transfer embryos activated with different combination of chemicals. Mol. Reprod. Dev. 2006;73:10941101. DOI $10.1002 / \mathrm{mrd} .20455$.

Jaenisch R. Nuclear cloning and direct reprogramming: the long and the short path to Stockholm. Cell Stem Cell. 2012;11(6):744-747. DOI 10.1016/j.stem.2012.11.005.

Jin Y., Zhang M., Ju X., Liang S., Xiong Q., Zhao L., Nie X., Hou D., Liu Q., Wang J., Wang C., Li X., Zhang L., Liu X., Wang Y., Yang H., Dai Y., Li R. Factors influencing the somatic cell nuclear transfer efficiency in pigs. Front. Agr. Sci. Eng. 2019;6(1):73-83. (2018. Epub ahead of print). DOI 10.15302/J-FASE-2018220. 
Ju S., Rui R., Lu Q., Lin P., Guo H. Analysis of apoptosis and methyltransferase mRNA expression in porcine cloned embryos cultured in vitro. J. Assist. Reprod. Genet. 2010;27(1):49-59. DOI 10.1007/ s10815-009-9378-7.

Kawakami M., Tani T., Yabuuchi A., Kobayashi T., Murakami H., Fujimura T., Kato Y., Tsunoda Y. Effect of demecolcine and nocodazole on the efficiency of chemically assisted removal of chromosomes and the developmental potential of nuclear transferred porcine oocytes. Cloning Stem Cells. 2003;5(4):379-387. DOI 10.1089/ 153623003772032871.

Kim Y.S., Lee S.L., Ock S.A., Balasubramanian S., Choe S.Y., Rho G.J. Development of cloned pig embryos by nuclear transfer following different activation treatments. Mol. Reprod. Dev. 2005;70:308-313. DOI $10.1002 / \mathrm{mrd} .20211$

Kong Q.R., Luo Y.B., Tian J.T., Wang Z.K., Zhang L., Liu Z.H. Production of porcine reconstructed embryos by whole-cell intracytoplasmic microinjection (Article in Chinese). Fen Zi Xi Bao Sheng Wu Xue Bao. 2008;41(1):70-74.

Koo D.B., Chae J.I., Kim J.S., Wee G., Song B.S., Lee K.K., Han Y.M. Inactivation of MPF and MAP kinase by single electrical stimulus for parthenogenetic development of porcine oocytes. Mol. Reprod. Dev. 2005;72:542-549. DOI 10.1002/mrd.20382.

Kragh P.M., Vajta G., Corydon T.J., Purup S., Bolund L., Callesen H. Production of transgenic porcine blastocysts by hand-made cloning. Reprod. Fertil. Dev. 2004;16:315-318. DOI 10.10371/RD04007.

Kues W.A., Carnwath J.W., Paul D., Niemann H. Cell cycle synchronization of porcine fetal fibroblasts by serum deprivation initiates a nonconventional form of apoptosis. Cloning Stem Cells. 2002;4(3): 231-243. DOI 10.1089/15362300260339511.

Lee E., Estrada J., Piedrahita J. Comparative study on the efficiency of two enucleation methods in pig somatic cell nuclear transfer: effects of the squeezing and the aspiration methods. Anim. Biotechnol. 2008;19(2):71-79. DOI 10.1080/10495390701839264.

Lee J.W., Wu S.C., Tian X.C., Barber M., Hoaqland T., Riesen J., Lee K.H., Tu C.F., Cheng W.T., Yang X. Production of cloned pigs by whole-cell intracytoplasmic microinjection. Biol. Reprod. 2003; 69:995-1001. DOI 10.1095/biolreprod.103.015917.

Liu Y., Zeng B.H., Shang H.T., Cen Y.Y., Wei H. Bama miniature pigs (Sus scrofa domestica) as a model for drug evaluation for humans: comparison of in vitro metabolism and in vivo pharmacokinetics of lovastatin. Comp. Med. 2008;58:580-587.

Marteil G., Richard-Parpaillon L., Kubiak J.Z. Role of oocyte quality in meiotic maturation and embryonic development. Reprod. Biol. 2009;9(3):203-224. DOI 10.1016/S1642-431X(12)60027-8.

McGrath J., Solter D. Nuclear transplantation in the mouse embryo by microsurgery and cell fusion. Science. 1983;220:1300-1302. DOI 10.1002/jez.1402280218

Miao Y.L., Kikuchi K., Sun Q.Y., Schatten H. Oocyte aging: cellular and molecular changes, developmental potential and reversal possibility. Hum. Reprod. Update. 2009;15(5):573-585. DOI 10.1093/ humupd/dmp014.

Miao Y., Ma S., Liu X., Miao D., Chang Z., Luo M., Tan J. Fate of the first polar bodies in mouse oocytes. Mol. Reprod. Dev. 2004;69: 66-76. DOI 10.1002/mrd.20148.

Nickoloff J.A. (Ed.) Animal Cell Electroporation and Electrofusion Protocols. In: Ser. "Methods in Molecular Biology". Vol. 48. Totowa, NJ: Humana Press, 1995.

Niemann H., Kues W.A., Lucas-Hahn A., Carnwath J.W. Somatic cloning and epigenetic reprogramming in mammals. In: Atala A., Lanza R., Thompson J., Nerem R. (Eds.) Principles in Regenerative Medicine. 2nd edn. Academic Press, 2011:148-167.

Oback B., Wiersema A.T., Gaynor P., Laible G., Tucker F.C., Oliver J.E., Miller A.L., Troskie H.E., Wilson K.L., Forsyth J.T., Berg M.C., Cockrem K., McMillan V., Tervit H.R., Wells D.N. Cloned cattle derived from a novel zona-free embryo reconstruction system. Cloning Stem Cells. 2003;5(1):3-12. DOI 10.1089/153623003321512111.

Onishi A., Iwamoto M., Akita T., Mikawa S., Takeda K., Awata T., Hanada H., Perry A.C. Pig cloning by microinjection of fetal fibro- blast nuclei. Science. 2000;289:1188-1190. DOI 10.1126/science. 289.5482.1188

Park H.J., Koo O.J., Kwon D.K., Kang J.T., Jang G., Lee B.C. Effect of roscovitine-treated donor cells on development of porcine cloned embryos. Reprod. Domest. Anim. 2010;45(6):1082-1088. DOI 10.1111/j.1439-0531.2009.01499.x.

Peng H., Liu F.J., Zhang X.F., Zhuang Y.F., Wang X.A., Li H.X., Hong Z.Y., Lin X.J., Zhang W.C. Study of electro-fusion/activation in somatic cell nuclear transfer to obtain cloned putian black pig embryos. J. Anim. Vet. Adv. 2013;12(4):497-503. DOI 10.3923/ javaa.2013.497.503

Polejaeva I.A., Chen S.H., Vaught T.D., Page R.L., Mullins J., Ball S., Dai Y., Boone J., Walker S., Ayares D.L., Colman A., Campbell K.H. Cloned pigs produced by nuclear transfer from adult somatic cells. Nature. 2000;407:8690. DOI 10.1038/35024082.

Popova E., Bader M., Krivokharchenko A. Efficient production of nuclear transferred rat embryos by modified methods of reconstruction. Mol. Reprod. Dev. 2009;76:208-216. DOI 10.1002/mrd.20944.

Presicce G.A., Yang X.Z. Parthenogenetic development of bovine oocytes matured in vitro for $24 \mathrm{hr}$ and activated by ethanol and cycloheximide. Mol. Reprod. Dev. 1994;38:380-385. DOI 10.1002/ mrd.1080380405.

Rim C.H., Fu Z., Bao L., Chen H., Zhang D., Luo Q., Ri H.C., Huang H., Luan Z., Zhang Y., Cui C., Xiao L., Jong U.M. The effect of the number of transferred embryos, the interval between nuclear transfer and embryo transfer, and the transfer pattern on pig cloning efficiency. Anim. Reprod. Sci. 2013;143(1-4):91-96. DOI 10.1016/ j.anireprosci.2013.10.004.

Robl J.M., Prather R.S., Branes F., Eyestone W., Northey D., Gilligan B., First N.L. Nuclear transplantation in bovine embryos. J. Anim. Sci. 1987;64:642-647.

Samiec M., Skrzyszowska M. The use of different methods of oocyte activation for generation of porcine fibroblast cell nuclear transferred embryos. Ann. Anim. Sci. 2010;10(4):399-411.

Savard C., Novak S., Saint-Cyr A., Moreau M., Pothier F., Sirard M.A. Comparison of bulk enucleation methods for porcine oocytes. Mol. Reprod. Dev. 2004;67(1):70-76. DOI 10.1002/mrd.20011.

Shi J., Zhou R., Luo L., Mai R., Zeng H., He X., Liu D., Zeng F., Cai G., Ji H., Tang F., Wang Q., Wu Z., Li Z. Influence of embryo handling and transfer method on pig cloning efficiency. Anim. Reprod. Sci. 2015;154:121-127. DOI 10.1016/j.anireprosci.2015.01.006.

Simões R., Santos A.R., Jr. Factors and molecules that could impact cell differentiation in the embryo generated by nuclear transfer. Organogenesis. 2017;13(4):156-178. DOI 10.1080/15476278.2017. 1389367.

Singina G.N., Volkova N.A., Bagirov V.A., Zinovieva N.A. Cryobanking of somatic cells in conservation of animal genetic resources: prospects and successes. Selskokhozyaistvennaya Biologiya = Agricultural Biology. 2014;6:3-14. DOI 10.15389/agrobiology. 2014.6.3eng.

Skrzyszowska M., Samiec M., Słomski R., Lipiński D., Mały E. Development of porcine transgenic nuclear-transferred embryos derived from fibroblast cells transfected by the novel technique of nucleofection or standard lipofection. Theriogenology. 2008;70:248-259. DOI 10.1016/j.theriogenology.2008.04.007.

Sugimura S., Yamanaka K., Kawahara M., Wakai T., Yokoo M., Sato E. Early metaphase II oocytes treated with dibutyryl cyclic adenosine monophosphate provide suitable recipient cytoplasm for the production of miniature pig somatic cell nuclear transfer embryos. Anim. Sci. J. 2010;81(1):48-57. DOI 10.1111/j.1740-0929.2009.00705.x.

Suzuki C., Iwamura S., Yoshioka K. Birth of piglets through the nonsurgical transfer of blastocysts produced in vitro. Reprod. Dev. 2004; 50(4):487-491.

Tatham B.G., Dowsing A.T., Trounson A.O. Enucleation by centrifugation of in vitro-matured bovine oocytes for use in nuclear transfer. Biol. Reprod. 1995;53:1088-1094. DOI 10.1095/biolreprod53.5.1088.

Uhm S.J., Gupta M.K., Chung H.J., Kim J.H., Park C., Lee H.T. Relationship between developmental ability and cell number of Day 2 
porcine embryos produced by parthenogenesis or somatic cell nuclear transfer. Asian-Australas. J. Anim. Sci. 2009;22(4):483-491. DOI 10.5713/ajas.2009.80362.

Vacková I., Engelová M., Marinov I., Tománek M. Cell cycle synchronization of porcine granulosa cells in G1 stage with mimosine. Anim. Reprod. Sci. 2003;77(3-4):235-245. DOI 10.1016/S03784320(03)00034-4.

Vajta G., Kragh P.M., Mtango N.R., Callesen H. Hand-made cloning approach: potentials and limitations. Reprod. Fertil. Dev. 2005; 17(1-2):97-112. DOI 10.1071/RD04116.

Vajta G., Lewis I.M., Hyttel P., Thouas G., Trounson A. Somatic cell cloning without micromanipulators. Cloning. 2001;3:89-95. DOI $10.1089 / 15204550152475590$.

Verma P.J., Du Z.T., Crocker L., Faast R., Grupen C.G., McIlfatrick S.M., Ashman R.J., Lyons I.G., Nottle M.B. In vitro development of porcine nuclear transfer embryos constructed using fetal fibroblasts. Mol. Reprod. Dev. 2000;57(3):262-226. DOI 10.1002/ 1098-2795(200011)57:3<262::AID-MRD8>3.0.CO;2-X.

Whitworth K.M., Li R., Spate L.D., Wax D.M., Rieke A., Whyte J.J., Manandhar G., Sutovsky M., Green J.A., Sutovsky P., Prather R.S. Method of oocyte activation affects cloning efficiency in pigs. Mol. Reprod. Dev. 2009;76:490-500. DOI 10.1002/mrd.20987.

Wilmut I., Schnieke A.E., McWhir J., Kind A.J., Campbell K.H. Viable offspring derived from fetal and adult mammalian cells. Nature. 1997;385:810-813. DOI 10.1089/clo.2006.0002.

Wimmers K., Murani E., Ponsuksili S. Functional genomics and genetical genomics approaches towards elucidating networks of genes affecting meat performance in pigs. Brief. Funct. Genomics. 2010;9: 251-258. DOI 10.1093/bfgp/elq003.
Yamanaka K., Sugimura S., Wakai T., Kawahara M., Sato E. Difference in sensitivity to culture condition between in vitro fertilized and somatic cell embryos in pigs. Reprod. Dev. 2009;55(3):299-304. DOI 10.1262/jrd.20174.

Yang F., Hao R., Kessler B., Brem G., Wolf E., Zakhartchenko V. Rabbit somatic cell cloning: effects of donor cell type, histone acetylation status and hymeric embryo-complementation. Reproduction. 2007;133(1):219-230. DOI 101530/rep.1.01206.

Yin X.J., Tani T., Yonemura I., Kawakami M., Miyamoto K., Hasegaw R., Kato Y., Tsunoda Y. Production of cloned pigs from adult somatic cells by chemically assisted removal of maternal chromosomes. Biol. Reprod. 2002;67:442-446. DOI 10.1095/biolreprod 67.2.442.

Yoshioka K., Suzuki C., Tanaka A., Anas I.M., Iwamura S. Birth of piglets derived from porcine zygotes cultured in a chemically defined medium. Biol. Reprod. 2002;66(1):112-119.

Zhang Y., Pan D., Sun X., Sun G., Wang X., Liu X., Li Y., Dai Y., Li N. Production of porcine cloned transgenic embryos expressing green fluorescent protein by somatic cell nuclear transfer. Sci. China C. Life Sci. 2006;49(2):164-171. DOI 10.1007/s11427-005-0071-5.

Zheng Y.M., Zhao H.Y., Zhao X.E., Quan F.S., Hua S., He X.Y., Liu J., He X.N., Lin H. Development of cloned embryos from porcine neural stem cells and amniotic fluid-derived stem cells transfected with enhanced green fluorescence protein gene. Reproduction. 2009; 137(5):793-801. DOI 10.1530/REP-08-0469.

Zhu J., Telfer E.E., Fletcher J., Springbett A., Dobrinsky J.R., De Sousa P.A., Wilmut I. Improvement of an electrical activation protocol for porcine oocytes. Biol. Reprod. 2002;66(3):635-641. DOI 10.1095/biolreprod66.3.635.

ORCID ID

A.V. Lopukhov orcid.org/0000-0002-1284-1486

G.N. Singina orcid.org/0000-0003-0198-9757

N.A. Zinovieva orcid.org/0000-0003-4017-6863

Conflict of interest. The authors declare no conflict of interest.

Received February 5, 2019. Revised May 20, 2019. Accepted May 20, 2019. 